Annals of Warsaw University of Life Sciences - SGGW

Land Reclamation No 50 (3), 2018: 263-272

(Ann. Warsaw Univ. of Life Sci. - SGGW, Land Reclam. 50 (3), 2018)

\title{
Phytotoxicity and phytogenotoxicity of soils in the area of liquidated pesticide-burial ground
}

\author{
GRAŻYNA OBIDOSKA, ZBIGNIEW M. KARACZUN, SARA KONOFALSKA, \\ BARBARA ŻARSKA \\ Faculty of Horticulture, Biotechnology and Landscape Architecture, Warsaw University of Life \\ Sciences-SGGW
}

\begin{abstract}
Phytotoxicity and phytogenotoxicity of soils in the area of liquidated pesticide-burial ground. First efforts to reduce the environmental risks caused by existing pesticide burial grounds were undertaken in Poland at the beginning of the 1990s. Work on their liquidation was accelerated after the adoption of the first National Waste Management Plan 2006 and National Waste Management Plan 2010. In 2011 The Supreme Audit Office carried out an assessment of the realisation of the plans, which revealed the negligence in monitoring of the areas of liquidated pesticide burial grounds, whilst even after the land reclamation process, the remaining contamination could still pose environmental risk. In such areas, to evaluate the impact of the mixture of potentially present toxic and genotoxic substances, higher plant bioassays are very useful. On the example of liquidated pesticide burial ground in Grójec we concluded, that after several years from the liquidation and land reclamation processes, environmental impact of this type of facility could still be perceptible. Phytogenotoxicity of soil samples, collected from the liquidated burial site and the immediate vicinity, was detected with Vicia faba Root Tip Assay.
\end{abstract}

Key words: pesticide burial ground, phytotoxicity, phytogenotoxicity, Vicia faba RTA

\section{INTRODUCTION}

The problem of utilization of obsolete pesticides appeared in 20th century. The first attempts to solve this issue in Po- land were undertaken in the 1960s. Pesticides were initially buried directly in the earth pits throughout the whole country (Wołkowicz et al. 2010). In 1971, the guidelines for the construction storage sites appeared and they recommended to build underground reservoirs made of concrete rings, with the diameter of 1-2 $\mathrm{m}$ and the depth of 3-4 m (Centralny Związek Spółdzielczości Rolników 1971). Unfortunately, the above mentioned instruction did not impose hermeticity checking of these facilities, nor did it contain requirements regarding their location. Therefore, often the pesticide burial sites were located on groundwater supply areas, posing risk for water consumers (Biegańska et al. 2013).

At the beginning of the 21 st century, the total mass of obsolete pesticides in the world was estimated at 400,000-500,000 Mg (Biegańska et al. 2013), with large stocks in Central and Eastern Europe (Kocur-Bera 2013). The amount of this type of substances deposited in Poland is not known in detail. According to the assessment of the Ministry of the Environment of 2010, their weight was $2,567.81$ Mg (Ignatowicz 2013). First efforts to reduce the environmental risks caused by existing pesticide burial grounds were 
undertaken in the the 1990s, but works on their liquidation accelerated after the adoption of the first National Waste Management Plan 2006 which assumed that the existing pesticide tombs in the country would be removed by the end of 2010 . This objective was maintained in the next National Waste Management Plan 2010.

In 2011 The Supreme Audit Office (Najwyższa Izba Kontroli 2012) carried out an assessment of the extent to which this objective has been achieved. It showed that many of the burial grounds have been liquidated, but at the scheduled time not all of them. Moreover it revealed the negligence in monitoring of the areas of liquidated pesticide tombs: it was carried out only for $30 \%$ of sites. In the majority of cases, even the status of waters in the immediate vicinity was not being checked.

The monitoring of the area of liquidated pesticide tomb seems absolutely obligatory, to be sure that all the threats to the natural environment have been mitigated. Even after the extermination and land reclamation process, the remaining contamination could still pose risk for nature and also for human health (Ignatowicz 2013, Kocur-Bera 2013). It is worth reminding that natural flora may be sensitive to genotoxic pollutants in soil and/or air even at very low concentrations (Greguskova and Micieta 2013). They may possibly lead to decrease in plant reproduction ability with consequences for the process of succession (Pflugshaupt et al. 2002).

In such areas, to evaluate the impact of the mixture of potentially present toxic and genotoxic substances, higher plant bioassays are very useful. They are relatively inexpensive and well suited to evaluate environmental hazards to ecosystems (Gopalan 1999). In our research we assessed the phytotoxicity and also phytogenotoxicity of soils in the liquidated pesticide burial area in Grójec. Our aim was to determine, on the basis of this example, whether any environmental impact may be perceptible several years after the liquidation of a pesticide tomb and the land reclamation process.

\section{RESEARCH AREA AND METHODS}

\section{Research area}

The pesticide-burial site was located in the unused agricultural area, in the south-western part of the city of Grójec, at Mogielnicka street. It consisted of 29 wells made of concrete rings with an internal diameter of $840-1,200 \mathrm{~mm}$ and a depth of 2.4-3.5 m below ground level. Five wells were not equipped with a concrete bottom. The facility also included a ground pit measuring $1.5 \times 2.1 \times 0.4 \mathrm{~m}$ and of a volume of approx. $1.26 \mathrm{~m}^{3}$.

In October, 2007, the Community Office in Grójec signed a contract for the liquidation of the burial site and reclamation of the area. The works were carried out from 7 November 2007 to 9 January 2008. In the first stage pesticides and packaging materials were taken out of the wells and the ground pit, transported to the hazardous waste incinerator in Dąbrowa Górnicza and inactivated. Next the contaminated soil (to a depth of $4 \mathrm{~m}$ ) and concrete well constructions were extracted. This material was taken to the hazardous waste landfill in Gorzów Wielkopolski. In total, $490.77 \mathrm{Mg}$ of hazardous waste were removed (Table 1). 
TABLE 1. Amount of waste extracted during the liquidation of the pesticide burial ground in Grójec (Kucharski et al. 2008)

\begin{tabular}{|l|c|c|}
\hline Type of extracted waste & $\begin{array}{c}\text { Waste } \\
\text { code }\end{array}$ & $\begin{array}{c}\text { Amount of extracted waste } \\
(\mathrm{Mg})\end{array}$ \\
\hline $\begin{array}{l}\text { Agrochemical waste containing hazardous substances, } \\
\text { including plant protection products of } \\
\text { I and II toxicity class (very toxic and toxic) }\end{array}$ & $020108^{*}$ & 58.24 \\
\hline Soil, including stones, containing dangerous substances & $170503^{*}$ & 370.11 \\
\hline $\begin{array}{l}\text { Mixed or segregated waste from concrete, brick rubble, } \\
\text { ceramic waste and equipment items containing hazardous } \\
\text { substances }\end{array}$ & $170106^{*}$ & 62.42 \\
\hline
\end{tabular}

*Additionally mark hazardous waste.

The final stage of works was the reclamation of the area $\left(120 \mathrm{~m}^{2}\right)$; the bottom of the excavation was filled with a $1 \mathrm{~m}$ thick layer of loam with a low infiltration rate $(<8-10 \mathrm{~m} / \mathrm{s})$. Next, a $2.7 \mathrm{~m}$ layer of pure native soil was applied and covered with $0.3 \mathrm{~m}$ thick sand and peat mixture. For underground water monitoring purpose one piezometer was installed $(27 \mathrm{~m})$. Ground waters are being checked in 2 dug wells at private properties (Matracka et al. 2012).

\section{Soil sampling}

Soil samples were taken, using Egner's sampling stick, from 4 points: samples M20 and M40 - at the liquidated burial ground itself, at $20 \mathrm{~cm}$ depth and at $40 \mathrm{~cm}$ depth respectively; sample P2 at $200 \mathrm{~m}$ distance from the burial site in Northern direction, sample P3 - at 200 m distance in Eastern direction, sample P4 - at $200 \mathrm{~m}$ and sample P5 - at $400 \mathrm{~m}$ distances in Western direction. In each point 18-20 individual samples from the surface layer $(0-20 \mathrm{~cm})$ and in case of sample M40, from the subsurface layer $(20-40 \mathrm{~cm})$ were taken. The mixture of individual samples constituted a representative sample for each check point.

\section{Phytotoxicity assessment}

For phytotoxicity assessment Seedling Emergence and Growth Tests with $\mathrm{Vi}$ cia faba and Synapis alba were applied. Seeds were sown in $25 \mathrm{ml}$ containers filled with examined soil. As the control sample rinsed river sand was used. In case of Vicia faba 5 seeds, and in case of Synapis 10 seeds were placed in each pot, in 5 replications. Seedling emergence was observed, and subsequently after 5 days Synapis seedlings were replaced from the pots and their roots measured. In case of Vicia the process of germination was longer, so the seedlings were replaced and the roots measured after 14 days.

\section{Phytogenotoxicity assessment}

For phytogenotoxicity assessment Vicia faba RTA (Root Tip Assay) was used. The seeds were germinated in rinsed river sand. After achieving the main root about 2-3 cm long they were placed in soil samples and the control in sand. After 3 days of exposition the roots were cut off, rinsed in water and fixed in Carnoy's solution (ethanol and glacial acetic acid $3: 1)$ for $24 \mathrm{~h}$. Then they were rinsed and stored in $70 \%$ ethanol in a fridge. 
Microscope slide preparation started with root maceration in $1 \mathrm{~N} \mathrm{HCl}$ for $40 \mathrm{~min}$ in room temperature and staining in acetoorcein for about $2 \mathrm{~h}$. For each combination 5 microscopic slides were prepared and the mitotic indices (MI) in $5 \times 1,000$ meristematic cells were calculated according to the following formula:

$$
M I=\left(\frac{M}{T}\right) \cdot 100 \%
$$

$M$ - number of dividing cells;

$T$ - total number of cells.

Next step was to assess the percentage of chromosomal aberrations (such as: bridges, fragments or vagrant chromosomes) in $5 \times 200$ anaphase and telophase cells (AAT).

$A A T=\left(\frac{A T_{\text {abnorm }}}{A T_{\text {all }}}\right) \cdot 100 \%$

$A T_{\text {abnorm }}$ - abnormal anaphase and telophase cells;

$A T_{\text {all }} \quad$ - total number of anaphase and telophase cells.

Test results were subjected to the Statistica 13.3 computer program. After One-way Analysis of Variance (ANOVA), we used Tukey's honestly significant difference (HSD) post hoc test at a significance level of $P<0.05$.

\section{RESULTS AND DISCUSSION}

Liquidated pesticide burial grounds may pose danger for the surrounding soils and waters for many years after the reclamation process (Ignatowicz 2018). According to Gałuszka et al. (2011) in Poland there were 124 unsatisfactory remedia- tion projects of pesticide burial ground liquidation. Monitoring was carried out only for $30 \%$ of sites, being neglected in the rest of them (Najwyższa Izba Kontroli 2012), and it indicated that in some places the quality of ground-waters did not meet the standards. The quality of soils was rarely checked, because most of the soil from liquidated burial grounds had been removed ( $1 \mathrm{~m}$ thick layer underlying the containers and $0,5 \mathrm{~m}$ thick layer adhering to the containers Gałuszka et al. 2011) and the rest was supposed to be cleaned up by biological processes. Unfortunately for some substances, for example organochlorine pesticides (OCP), it takes decades (Liu et al. 2015). Soil may serve as storage compartment for them as they have limited water solubility and tend to be sorbed on soil particles (Stark et al. 1987). On the other hand in higher temperatures in summer, being volatile, they may be released into the upper soil layers and the atmosphere (Alamdar et al. 2014).

We do not have the detail data of kind of pesticides in Grójec burial ground but, according to Gałuszka et al. (2011), typical content of a pesticide tomb in Poland was dominated by OCP (10-100\% waste volume) with DDT insecticide as the prevailing compound. Soil monitoring at Grójec site in 2011-2012, at 4 m depth, detected the presence of OCP, such as: aldrine, dieldrine, DDT and its metabolites DDD, DDE, and some other groups of pesticides. The quantities were not exceeding standards for the certain kind of soil (Matracka et al. 2012), but in the upper layers they were not checked.

Downward movement of pesticides in soils is of course the main direction, but in case of DDT, or other high molecular 
weight halogenated organic compounds, it is limited (Lippmann et al. 2003). Low solubility suggests that leaching will not be a major route of loss in this case (Boul 1995). There may also be the upward movement, due to evaporation, which has been underestimated for years. Certain compounds may volatilize from even deep subsurface locations (Jury et al. 1990, 1992). DDT, especially converted in soil to DDE, has a volatile nature and may be quite easily lost by evaporation (Boul 1995).

In our studies we performed phytotoxicity and phytogenotoxicity testing of surface backfill soils, in order to check their potential contamination with the remaining pesticides through volatilization from the deeper layers. It was already reported (Gill et al. 1991) that, even after the remediation process, the surface soils at chemical waste sites, might be genotoxic to plant bioindicators.

Phytotoxicity seedling tests may have many endpoints, but in pot experiments the seedling shoot emergence and root elongation are normally used. In our research neither the emergence of shoots, nor the elongation of roots, which is a more sensitive parameter (An 2004), in both test species: Synapis alba and Vicia faba, did indicate toxicity of examined soils (Fig. 1). However, it must be mentioned, that some plant species such as Artemisia annua, Amaranthus retroflexus, Kochia scoparia and others, are known to be resistant to pesticides, including OCP. They accumulate OCP in root system and it is not preventing them from producing high biomass. They do not show any toxic symptoms and they may possibly be used for phytoremediation purposes (Nurzhanova et al. 2013).
Perhaps Vicia and Synapis used in our experiment were also tolerant enough not to show inhibition of seedling emergence and root elongation.

Species such as Vicia faba, Allium cepa, Tradescantia paludosa have ability to detect phytogenotoxicity of chemical agents and they are currently in use for this purpose in environmental studies (Ma et al. 2005). For phytogenotoxicity testing we used Vicia faba Root Tip Assay, which is highly recommended for soil samples (Cotelle et al. 2015) and known as sensitive to DDT and DDE as genotoxic agents (Juarez-Santacruz et al. 2015). Initially the mitotic indices were calculated. In comparison with control, the soil samples collected from surface layer of $20 \mathrm{~cm}$, from any of the points, did not inhibit mitosis of the meristematic root cells. Only in case of soil sample M40, taken from subsurface layer 20$-40 \mathrm{~cm}$, at the burial ground, the mitotic index was significantly lower than in the control one. The substances present in the sample inhibited mitosis by over $50 \%$ (Fig. 2). Similar inhibition in $M I$ was observed in Vicia after treatment with Cyolan organophosphorus insecticide (George and Ghareeb 2001).

Observations of anaphase and telophase cells indicated significantly higher number of aberrations (AAT), such as: chromosomal bridges, vagrant chromosomes and fragments of chromosomes, in any of the examined soil samples in comparison with control. We concluded that the soil samples from each of the points showed phytogenotoxic effects on meristematic cells of Vicia faba roots. The highest one (about 30\% AAT) was observed for sample M40 from the point located at liquidated burial site $40 \mathrm{~cm}$ 

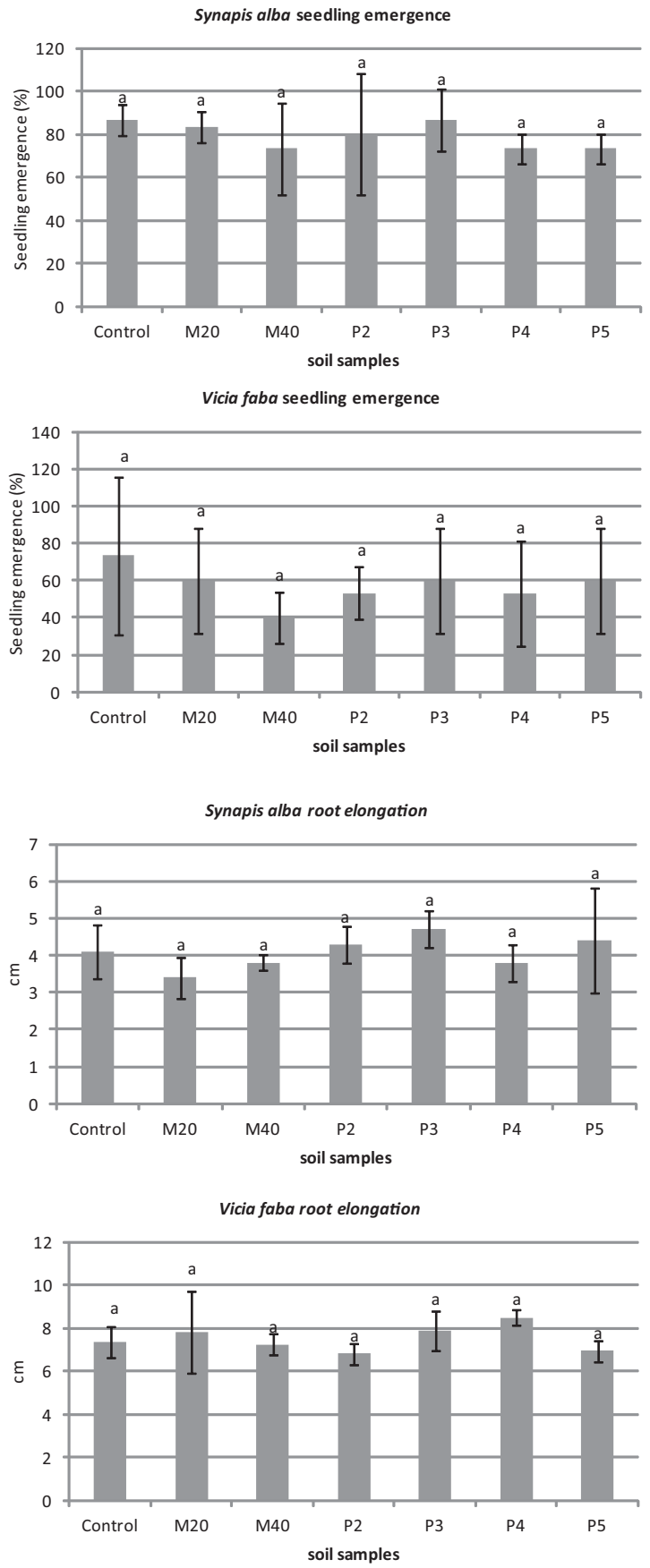

FIGURE 1. Seedling emergence and root elongation in Synapis alba and Vicia faba in soil samples collected from the liquidated pesticide burial ground and its vicinity. Means with the same letter do not differ significantly 

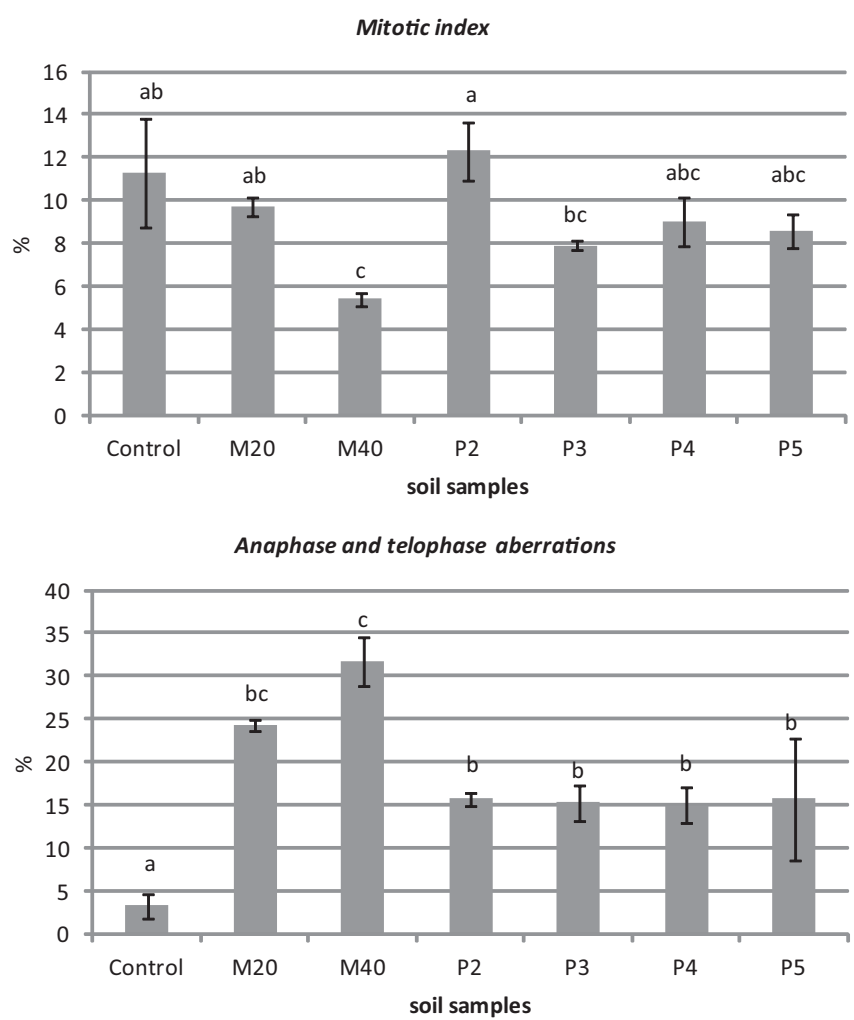

FIGURE 2. Mitotic index (MI) and anaphase and telophase aberrations (AAT) in Vicia faba root tip meristematic cells in soil samples collected from the liquidated pesticide burial ground and its vicinity. Means with the same letter do not differ significantly

deep. Again similar effect of Cyolan was observed in Vicia (George and Ghareeb 2001). Soil samples from other points, showed similar genotoxicity level, but it was significantly lower than on the burial ground itself (Fig. 2). It seems natural that concentration of genotoxic agent was decreasing in points distant from the burial ground. Such relation was also reported by Alamdar et al. (2014).

Genotoxic effect observed in our research concerned root cells, but it is proved that contaminants uptaken by roots from soil, may be translocated to the over ground part of plant, with ef- ficiency depending on the species (Nurzhanova et al. 2013). In areas with contaminated soils, disturbances were observed in generative parts of plants in several native species: Chelidonium majus, Clematis vitalba, Cichorium intybus, Linaria vulgaris (Misik et al. 2007), and also Artemisia vulgaris, Melilotus albus, Trifolium pretense, Salix caprea, Lamium maculatum and others (Solenska et al. 2006, Greguskova and Micieta 2013). Aberrations in tetrads after the meiosis may lead to abnormal microspores, the production of abortive pollen grains and in consequence certain percentage 
of empty seeds. Pollen limitation is especially affecting winter declining species, because their reproductive success and persistence mostly depends on seeds (Pflugshaupt et al. 2002). Native plants responses to genotoxic substances can be observed even at very low concentrations (Greguskova and Micieta 2013) and may possibly lead to the decrease of plant reproduction ability with consequences for the process of succession in the area (Pflugshaupt et al. 2002).

\section{CONCLUSIONS}

1. On the example of liquidated pesticide burial ground in Grójec it was concluded, that after several years from the liquidation and land reclamation processes, environmental impact of this type of facilities can still be perceptible.

2. Although phytotoxicity of soils was not detected at the liquidated burial site or the immediate vicinity, phytogenotoxicity of the same soil samples was significant.

3. Phytogenotoxicity studies, using plant bioassays and native plant species, are recommended beside the chemical analysis of soils for full monitoring of liquidated pesticide burial grounds.

\section{REFERENCES}

ALAMDAR A., SYED J.H., MALIK R.N., KATSOYIANNIS A., LIU J., LI J., ZHANG G., JONES K.C. 2014: Organochlorine pesticides in surface soils from obsolete pesticide dumping ground in Hyderabad city, Pakistan: Contamina- tion levels and their potential for air-soil exchange. Science of the Total Environment 470-471: 733-741.

AN Y. (2004). Soil ecotoxicity assessment using cadmium sensitive plants. Environ. Pollution 127: 21-26.

BIEGAŃSKA J., HARAT A., ZYZAK W. 2013: Unieszkodliwianie odpadowych środków ochrony roślin pochodzących z mogilników metodą detonacyjnego spalania [Neutralizing of waste pesticides from dumping grounds by means of explosive burning]. Inż. Ekol. 33: 13- 20.

BOUL H.L. 1995: DDT residues in the environment $-\mathrm{A}$ review with a New Zealand perspective. New Zealand J. Agricult. Res. 38 (2): 257-277.

Centralny Związek Spółdzielczości Rolników 1971: Instrukcja $\mathrm{nr} 1 / 71 \quad \mathrm{z}$ 21.05.1971 r. w sprawie zasad i sposobów likwidacji niepełnowartościowych chemicznych środków ochrony roślin wycofanych z obrotu handlowego [Instruction No 1/71 of 21051971 concerning the rules and methods of liquidation of deficient chemical means of plant protection banned from the market]. CZSR, Warszawa.

COTELLE S., DHYEVRE A., MULLER S., CHENON P., MANIER N., PANDARD P., ECHAIRI A., SILVESTRE J., MARITXU G., PINELLI E., GIORGETTI L., BARBAFIERI M., SILVA V.C., ENGEL F., RADETSKI C.M. 2015: Soil genotoxicity assessment - results of an interlaboratory study on the Vicia micronucleus assay in the context of ISO standardization. Environ. Sci. and Poll. Res. 22: 988-995.

GAŁUSZKA A., MIGASZEWSKI Z.M., MANECKI P. 2011: Pesticide burial grounds in Poland: A review. Environment International 37: 1265-1272.

GEORGE N.M., GHAREEB A. 2001: Genotoxicity of the insecticide cyolan on mitosis, meiosis and seed storage proteins of Vicia faba. Cytologia 66: 77-84.

GILL B.S., SANDHU S.S., BACKER L.C., CASTO B.C. 1991: Application of 
a plant test system in the identification of potential genetic hazards at chemical waste sites. Plants for toxicity assessment 2. American Society for Testing and Materials, Philadelphia: 309-317.

GOPALAN H.N.B. 1999: Ecosystem health and human wellbeing: the mission of the international programme on plant bioassays. Mutation Res. 426: 99-102.

GREGUSKOVA E., MICIETA K. 2013: Phytoindication of the ecogenotoxic effects of vehicle emissions using pollen abortion test with native flora. Pol. J. Environ. Stud. 22 (4): 1069-1076.

IGNATOWICZ K. 2013: Mogilniki pestycydowe w Polsce - problem wciąż aktualny [Pesticide burial grounds in Poland - still current problem]. Ekon. Środ. 2 (45): 256-263.

IGNATOWICZ K. 2018: Pesticide burial grounds in Poland - Actuality Problem. J. Ecol Eng. 19 (3): 120-125.

JUAREZ-SANTACRUZ L., GARCIA-NIETO E., ROMO-GOMEZ C., ORTIZ-ORTIZ E., COSTILLA-SALAZAR R., LUNA-ZENDEJAS H.S. 2015: DNA damage in Vicia faba by exposure to agricultural soils from Tlaxcala, Mexico. Bull. Environ. Contam. Toxicol. 95 (6): 764-769.

JURY W.A., RUSSO D., STREILE G., EL ABD H. 1990: Evaluation of volatilization by organic chemicals residing below the soil surface. Water Resour. Res. 26: 13-20.

JURY W.A., RUSSO D., STREILE G., EL ABD H. 1992: Correction to evaluation of volatilization by organic chemicals residing below the soil surface. Water Resour. Res. 28 (2): 607-608.

KOCUR-BERA K. 2013: Analiza zagrożeń wynikających z lokalizacji tzw. „mogilników" na terenie wybranego województwa [Analysis of the hazard resulting from location of so-called "pesticide burial area" in selected region]. Infrastruktura i Ekologia Terenów Wiejskich 3 (3): 233-248.
KUCHARSKI R., WARZEC Ł., KACZYŃSKI B. 2008: Sprawozdanie z likwidacji składowiska przeterminowanych środków ochrony roślin (mogilnika) w Grójcu [Report from the liquidation of the obsolete pesticide burial ground in Grójec]. Gmina i powiat Grójec, Warszawa.

LIPPMANNM.,COHENB.S.,SCHLESINGER R.B. 2003: Environmental health science. Recognition, evaluation and control of chemical and physical health hazards. Oxford University Press, Oxford.

LIU L., BAI L., MAN C., LIANG W., LI F., MENG X. 2015: DDT vertical migration and formation of accumulation layer in pesticide-producing sites. Environ. Sci. Technol. 49 (15): 9084-9091.

MA T.H., CABRERA G.L., OWENS E. 2005: Genotoxic agents detected by plant boassays. Rev. Environ. Health 20 (1): 1-13.

MATRACKA E., WARDA J., SKUZA T. 2012: Raport. Ocena efektywności likwidacji mogilników w województwie mazowieckim na podstawie wyników badań monitoringowych za lata 2011-2012 [Report. Evaluation of the effectiveness of the liquidation of burial sites in the Mazowieckie voivodship on the basis of monitoring results for years 2011-2012]. WIOŚ, Warszawa.

MISIK M., MICIETA K., SOLENSKA M., MARKUSKOVA N., MISIKOVA K., KNASMULLER S. 2007: In situ monitoring of the genotoxic effects in the vicinity of a petrochemical plant with the Tradescantia micronucleus (Trad-MCN) and with pollen abortion test. BMC Pharmacology 7 (2), \# A53. https://doi. org/10.1186/1471-2210-7-S2-A53

Uchwała nr 219 Rady Ministrów z dnia 29 października 2002 r. w sprawie krajowego planu gospodarki odpadami 2006 [Resolution No. 219 of the Council of Ministers of October 29, 2002 on National Waste Management Plan 2006]. MP 2002 nr 11, poz. 159.

Uchwała nr 233 Rady Ministrów z dnia 29 grudnia 2006 r. w sprawie krajowego 
planu gospodarki odpadami 2010 [Resolution No 233 of the Council of Ministers of December 29, 2006 on National Waste Management Plan 2010]. MP 2006 nr 90, poz. 159.

Najwyższa Izba Kontroli 2012: Realizacja Krajowego Planu Gospodarki Odpadami 2010 w zakresie likwidacji mogilników. Informacja o wynikach kontroli [Implementation of the National Waste Management Plan 2010 in the field of liquidation of burial sites. Information about the results of inspection]. Retrieved from: http:// www.nik.gov. plik/id,3758,vp,4852.pdf [Accessed 06.07.2018].

NURZHANOVA A., KALUGIN S., ZHAMBAKIN K. 2013: Obsolete pesticides and application of colonizing plant species for remediation of contaminated soil in Kazakhstan. Environ. Sci. Pollut. Res. 20: 2054-2063.

PFLUGSHAUPT K., KOLLMANN J., FISCHER M., ROY B. 2002: Pollen quantity and quality affect fruit abortion in small populations of a rare fleshy-fruited shrub. Basic Appl. Ecol. 3: 319-327.

SOLENSKA M., MICIETA K., MISIK M. 2006: Plant bioassays for an in situ monitoring of air near an industrial area and municipal solid waste - Zilina (Slovakia). Environ. Monit. Assess. 115: 499-508.

STARK J.R., STRUDELL J.D., BLOOMGREN P.A., EGER P. 1987: Ground-water and soil contamination near two pesticide-burial sites in Minnesota. Water-Resources Investigation Report 87-4115. U.S. Geological Survey. St. Paul, Minnesota.

WOŁKOWICZ W., CHORMAŃSKI D., GLIWICZ T., STRZELECKI R., ANTOLAK O., KŁOS A., SIKORA P., KASZYCKI P. 2010: System integracji danych o mogilnikach (SIDOM). Synteza pracy [System of integration of data about burial sites (SIDOM). Work synthesis]. Państwowy Instytut Geolo- giczny - Państwowy Instytut Badawczy, Warszawa.

Streszczenie: Fitotoksyczność i fitogenotoksyczność gleb na terenie zlikwidowanego mogilnika pestycydowego. Pierwsze wysiłki w celu likwidacji zagrożeń spowodowanych przez istniejące mogilniki pestycydowe zostały podjęte w Polsce na początku lat 90. XX wieku. Prace likwidacyjne zostały przyspieszone po przyjęciu pierwszego Krajowego Planu Gospodarki Odpadami 2006 oraz następnego Krajowego Planu Gospodarki Odpadami 2010. W 2011 roku Najwyższa Izba Kontroli przeprowadziła ocenę realizacji planów, która ujawniła zaniedbania w monitoringu obszarów po zlikwidowanych mogilnikach, podczas gdy nawet po usunięciu mogilnika i rekultywacji terenu pozostałe zanieczyszczenia moga stwarzać zagrożenie dla środowiska. W takich rejonach do oceny wpływu mieszaniny potencjalnie toksycznych i genotoksycznych substancji bardzo użyteczne są testy $\mathrm{z}$ zastosowaniem roślin wyższych. Na przykładzie zlikwidowanego mogilnika pestycydowego w Grójcu stwierdzono, iż po kilku latach od likwidacji wpływ tego rodzaju instalacji na środowisko może pozostawać odczuwalny. Fitotogenoksyczność próbek gleby pobranych z terenu zlikwidowanego mogilnika oraz bezpośredniego sąsiedztwa stwierdzono za pomocą testu stożków wzrostu korzeni Vicia faba.

Stowa kluczowe: mogilnik pestycydowy, fitotoksyczność, fitogenotoksyczność, Vicia faba RTA

\section{MS received 15.06.2018 \\ MS accepted 16.07.2018}
Authors' address:
Grażyna Obidoska
Katedra Ochrony Środowiska
Wydział Ogrodnictwa, Biotechnologii
i Architektury Krajobrazu
ul. Nowoursynowska 159, 02-787 Warszawa
Poland
e-mail: grazyna_obidoska@sggw.pl 